\title{
A search for evidence of viral infection in pancreases of newly diagnosed patients with IDDM
}

\author{
A . K. Foulis ${ }^{1}$, M . M cG ill ${ }^{1}$, M . A . Farquharson ${ }^{1}$, D . A . H ilton ${ }^{2}$ \\ ${ }^{1} \mathrm{D}$ epartment of Pathology, R oyal Infirmary, G lasgow, U K \\ ${ }^{2} \mathrm{D}$ epartment of N europathology, Frenchay H ospital, B ristol, UK
}

Summary Techniques were developed to look for evidence of viral infection in formalin-fixed paraffinembedded autopsy pancreatic tissues from patients who had died of recent-onset insulin-dependent diabetes mellitus. D NA extracted from 47 pancreases in which good DNA preservation was confirmed was analysed by a polymerase chain reaction for $E$ pstein$B$ arr virus and by a nested polymerase chain reaction for cytomegalovirus. Histological sections from 29 pancreases in which there was good R NA preservation were tested for the presence of enterovirus and Epstein-Barr virus using in situ hybridization techniques. Seventy-five pancreases were analysed immunohistochemically for the presence of mumps virus. N one of these viruses could be detected in any of the diabetic pancreases studied. Control studies suggested that the techniques employed were as sensitive as culture done at the time of autopsy. Pancreas was available for study in 9 infants who had died of myocarditis; enterovirus was demonstrable in islets in 5 of these cases. A $n$ acute or persisting infection in the pancreas at the time of clinical onset of insulindependent diabetes by any of the 4 virus included in this study seems unlikely. [Diabetologia (1997) 40: 53-61]

Keywords Insulin - dependent diabetes mellitus, virus, enterovirus, myocarditis, mumps virus, Epstein$B$ arr virus, cytomegalovirus.
The most dramatic evidence for a role of viral infection in the pathogenesis of insulin-dependent diabetes mellitus (ID D M ) was the culture of a coxsackievirus $B_{4}$ from the autopsy pancreas of a 10-year-old boy who died of newly diagnosed diabetes [1]. Following inoculation of the viral isolate into mice, the animals developed islet endocrine cell necrosis and diabetes. $\checkmark$ irus could be demonstrated in the murine insulin containing beta cells. Previously, an untyped coxsackievirus $B$ had been demonstrated by immunofluorescence in the pancreas of a 5-year-old child who had died of IDDM and myocarditis 3 weeks after cardiac surgery [2]. There has also been supporting

R eceived: 3 J une 1996 and in revised form: 17 September 1996

Corresponding author: D r. A .K. Foulis, D epartment of Pathology, R oyal I nfirmary, G lasgow G 4 OSF, U K

A bbreviations: IDDM, Insulin-dependent diabetes mellitus; CM V, cytomegalovirus; E BV, E pstein-B arr virus. serological evidence linking enteroviral infection with IDDM. Coxsackievirus B specific IgM responses were detected in $29-33 \%$ of recently diagnosed diabetic patients, but only in $5-8 \%$ of normal control subjects [3].

$O$ ther viruses have been implicated in the aetiology of ID D M. M umps infection resulted in the transitory appearance of islet cell antibodies in $50 \%$ of infected children [4] and these antibodies persisted in some of those patients infected with mumps who also had subclinical pancreatitis [5]. Patients with congenital rubella have a considerably increased incidence of clinical diabetes [6], the disease tending to occur in those patients who also carry the HLA related genetic predisposition [7]. A nalysis of DNA from peripheral blood lymphocytes showed evidence of cytomegalovirus (CM V) infection in $22 \%$ of newly diagnosed IDDM patients but only in $2.6 \%$ of control subjects [8]. I slet cell membranes from newly diagnosed diabetic pancreases co-cultured with 
peripheral blood lymphocytes from normal donors preferentially stimulated $\mathrm{V}$ beta 7-positive T-cell clones out of $24 \mathrm{~V}$ beta $\mathrm{T}$-cell receptor families tested, suggesting the presence of a superantigen in the islet cell membranes [9]. A cute infectious mononucleosis caused by Epstein-Barr virus (EBV) is associated with selective over-expression of $\mathrm{V}$ beta 7 and $\mathrm{V}$ beta 6.1-3 T cells [10] and patients with newly diagnosed diabetes have been shown to have an abnormality of E BV specific immune responses [11]. These results raised the possibility that $E B V$ infection in diabetic islets could cause a superantigen effect.

$E$ vidence has accumulated to show that IDDM is a disease of slow evolution, with islet cell antibodies being present many years before clinical diagnosis [12]. Thus, the concept of a one hit cytopathic event by a virus causing beta-cell necrosis and diabetes has recently lost favour. However, many of the viruses thought to have a putative role are known to be capable of causing persistent or latent infection in man. The observation that beta cells in IDDM expressed interferon-alpha, a cytokine known to be induced by viral infection, supported the possibility that these cells harboured such persisting viruses [13].

The aim of the present study was to develop techniques for demonstrating the presence of candidate diabetogenic viruses in fixed archival autopsy pancreas that were as sensitive as viral culture of fresh autopsy tissue. If this could be done, an assessment could be made of how unusual was the culture of a virus from the pancreas of a patient with newly diagnosed IDDM [1]. Specifically, experiments were done to look for the presence of CMV, coxsackievirus $B, M$ umps virus and $E B V$.

\section{Subjects, materials and methods}

Selection of cases. Previous studies from this laboratory have involved the collection of formalin-fixed paraffin-embedded pieces of autopsy pancreas from patients with IDDM. M any of these patients died at the initial clinical presentation of their disease [14]. A II 75 pancreases selected for the present study had residual beta cells but further selection of cases was required for the different studies looking for CM V, EBV and coxsackie viruses, as described below.

CM V study. A nested polymerase chain reaction (PCR) technique was used to detect CMV (see below). DNA was extracted from single $10 \mu \mathrm{m}$ pancreatic sections and only those cases where the single copy $\beta$-globin gene was amplifiable in a separate PCR reaction were included. Thus, cases with poor preservation of tissue DNA were excluded. Of a total of 75 pancreases from patients with ID D M 47 satisfied these criteria. The age range of the patients was 6 months to 42 years (mean 11.9 years), the sex ratio was 27 female to 20 male, the duration of disease was known to be less than 1 year in 35 patients and insulitis was present in 42 . A Iso included in the study were 41 normal autopsy pancreases ( 9 from adults and 32 from children), tissues from 5 patients with clinical CM V infection and autopsy pancreas from 10 patients who had died from
A IDS, 3 of which had occasional CM V-infected cells demonstrable on routine immunocytochemistry.

Coxsackievirus study. In situ hybridization was employed for this part of the study and only those diabetic pancreases in which insulin mRNA and poly A mRNA tails could be detected by appropriate in situ hybridization methods were included. This ensured that only cases where there was good preservation of RNA in the tissues were studied. Pancreatic tissue from 29 of the 75 cases of IDDM fulfilled these requirements. The duration of disease was known to be less than 1 year in 20 and insulitis was present in 25 . The age range was 1-42 years with an average of 12.9 years and 10 patients were male. $O$ ther tissues examined in this study were a range of organs, including heart, from 14 children age range 3 days10 months), who had died of acute myocarditis. Here there were 12 males and 2 females and a coxsackievirus B was cultured either in life or at autopsy in 9 cases. In the remainder, either no culture was done, or the result was not available.

M umps virus study. A $n$ immunocytochemical method was used to detect mumps virus. Protein preservation, as witnessed by immunocytochemical demonstration of insulin, was present in all 75 diabetic pancreases collected. The age range of the patients was 6 months to 42 years with an average of 11.8 years. There were 45 females and 30 males and 56 patients were known to have been clinically diabetic for less than 1 year. The maximum duration of disease was 12 years and insulitis was present in 62 cases. 0 ther tissues examined included a variety of autopsy organs from 3 children (age range 4-16 years, 2 males, 1 female) who had died of mumps. Two of these patients had died of encephalitis and one of laryngeal oedema.

E BV studies. Two different methods were used - a PCR technique looking for viral DNA and an in situ hybridization technique to detect viral RNA. The PCR study examined the same 47 diabetic pancreases which were used in the CMV study, i.e. those pancreases where the $\beta$-globin gene was amplifiable. In situ hybridization for EBV RNA was performed on the same 29 diabetic pancreases as those used in the coxsackievirus study. These pancreases had well-preserved mR NA as described above. Two positive controls for EBV infection were included in each study. The first was a surgically removed formalin-fixed paraffin-embedded tonsil from a young man with a diagnosis of infectious mononucleosis. The second was a post-cardiac transplant lymphoproliferative lesion present in the lung of a 57-year-old male. The material studied had been removed at an autopsy performed $24 \mathrm{~h}$ after death.

\section{$\mathrm{L}$ aboratory methods}

CMV study. The protocol used in this study has been described previously [15]. B riefly, tissue sections $10 \mu \mathrm{m}$ thick were cut into sterile sample tubes ensuring no cross contamination between specimens. The wax was removed with xylene and alcohol and the sample dried under vacuum for approximately $10 \mathrm{~min}$. The resulting tissue was digested overnight at $37^{\circ} \mathrm{C}$ in $100 \mu \mathrm{l}$ of digestion buffer containing $500 \mu \mathrm{g} / \mathrm{ml}$ proteinase $\mathrm{K}$ and then boiled for $10 \mathrm{~min}$ [16]. A single PCR reaction was performed with $10 \mu \mathrm{l}$ of the resulting digest.

For the detection of CMV, DNA was amplified by PCR using a "G ene A mp" $\mathrm{K}$ it (Perkin Elmer Cetus, E meryville, Calif., USA ). Specific oligonucleotide primers were synthesised by $O$ swel DNA Services, (U niversity of Southampton, UK) to 
a highly conserved region of the intermediate-early gene of CMV [17, 18]. The initial pair of primers, (CMVA 1 and CM VA 2) (Table 1), amplified a 167 base pair product. The second set of internal primers, (CM V B 1 and CM V B 2) (Table 1), produced a 125 base pair product. In both rounds of amplification initial denaturation was carried out at $94^{\circ} \mathrm{C}$ for 8 min followed by cycles of $1 \mathrm{~min}$ denaturation at $94^{\circ} \mathrm{C}, 1 \mathrm{~min}$ annealing at $60^{\circ} \mathrm{C}$ and $1 \mathrm{~min}$ elongation of $72^{\circ} \mathrm{C}$. The first round of amplification consisted of 40 cycles. Four per cent of the product was then subjected to a second round of 30 cycles with the internal primers. We ran $50 \%$ of the final reaction mixture on a $2.5 \%$ agarose gel and visualised by ethidium bromide staining and transillumination in ultraviolet light.

O nly samples in which the $\beta$-globin gene could be detected were included in the $C M V$ study (see above). O ligonucleotide primers (BG 1 and BG 2, Table 1) were synthesized to the $\beta$ globin gene (0 swel) [19] and these amplified a 110 base pair product. The following cycling parameters were used: denaturation at $94^{\circ} \mathrm{C}$ for $5 \mathrm{~min}$ followed by 50 cycles of $1 \mathrm{~min}$ denaturation at $94^{\circ} \mathrm{C}, 30 \mathrm{~s}$ annealing at $60^{\circ} \mathrm{C}$ and $1 \mathrm{~min}$ elongation at $72^{\circ} \mathrm{C}$ and finally $1 \mathrm{cycle}$ of extension at $72^{\circ} \mathrm{C}$ for $5 \mathrm{~min}$. The conditions for visualisation of the product were as used for the CMV technique.

$G$ reat care was taken to avoid contamination by using sterile techniques and reagents. In each PCR run there was a positive control $(1 \mu \mathrm{l}$ from a proteinase $K$ digestion of a known positive $C M V$ infected autopsy pancreas and $5 \mu \mathrm{l}$ from a proteinase $\mathrm{K}$ digestion of normal tonsil for $\beta$-globin) and a negative control (distilled water).

In an effort to further test the sensitivity of the system for the detection of CM V, a single "owl's eye" CM V infected cell was microdissected from a section of infected neonatal pancreas along with a small amount of adjacent exocrine tissue (Fig. 1). DNA from this sample was extracted and amplified in the standard manner.

Coxsackievirus study. D etails of the in situ hybridization protocol have been published previously $[20,21]$. Cocktails of 6,30 mer DNA nucleotides were used as probes in the technique. Five of these were complementary to sequences in the $5^{\prime}$ noncoding region of the virus and the sixth complementary to sequences 7213-7184. The probes were labelled at the $3^{\prime}$ end using the homopolymer tailing method, incorporating digoxigenin 11-dU TP using terminal deoxynucleotide transferase [20]. In previous studies these probes have been shown to detect coxsackievirus B 1-5 in paraffin-embedded tissue sections of infected neonatal murine heart.

The basic method for the in situ hybridization technique in our laboratory has been described [22], but slight variations were used in this study. Following dewaxing and rehydration the slides were pre-treated in $2 \times$ Salt sodium citrate at $70^{\circ} \mathrm{C}$ for 30 min rather than Triton $X$ for 15 min as previously described. The coxsackievirus probe cocktail was used at a concentration of $0.1 \mathrm{ng} / \mu \mathrm{l}$ on 2 serial sections predigested with proteinase $K$ at 20 and $30 \mu \mathrm{g} / \mathrm{ml}$ respectively at $37^{\circ} \mathrm{C}$ for $30 \mathrm{~min}$. $\mathrm{H}$ ybridization was allowed to occur overnight at $42^{\circ} \mathrm{C}$. A $n$ alkaline phosphatase conjugated sheep anti-digoxigenin (B oehringer $\mathrm{M}$ annheim U K , L ewes, E ast Sussex, U K ) wasthen applied and the reaction visualised using nitroblue tetrazolium and bromo-chloroindolyl-phosphate (NBT, B CIP) (both Sigma, Poole, UK) dye solution as substrate [22]. Sections were treated with R N A -ase at a concentration of $100 \mu \mathrm{g} / \mathrm{ml}$ for $2 \mathrm{~h}$ at $37^{\circ} \mathrm{C}$ prior to hybridization of confirm that target sequences were R N A. Two positive controls were used in all runs. The first consisted of formalinfixed spinal cord and intercostal muscle tissue from a 3-day-old mouse infected at birth with coxsackievirus $B_{3}$. The second was a heart from a 13-day-old male infant who had died of acute
Table 1. Sequence of the primers used in PCR tests

$\mathrm{CMV}$ primers

CMVA 1

CM VA 2

5'TGG CAC GGG GAA TCC GCC T 3'

CM VB 1

5' GGTAGG CGT GTA CGG TGG G 3'

CMVB 2

5' GCA GA G CTC GTT TA G TGA A CC G 3'

5'A TC CGC GTT CCA ATG CAC CGT T 3'

E B V primers

EBVW 1 5'CACTTTAGA GCT CTG GAG GA 3'

EBVW $_{2}$ 5'TAA A GA TAG CA CAG CGCAG 3'

$\beta$-globin primers

$\begin{array}{ll}\text { BG } 1 & \text { 5'CA A CTT CA T CCA CGT TCA CC 3'} \\ \text { BG } 2 & \text { 5'A A CA CA CTG TGT TCA CTA GC 3'}\end{array}$

Sequence of the probes used in the in situ hybridization study

Insulin

TTG TTC CA C AAT GCC A CG CTT CTG

A rginine vasopressin

G GC CCG TCC A GC TGC GTG GCG TTG CTC

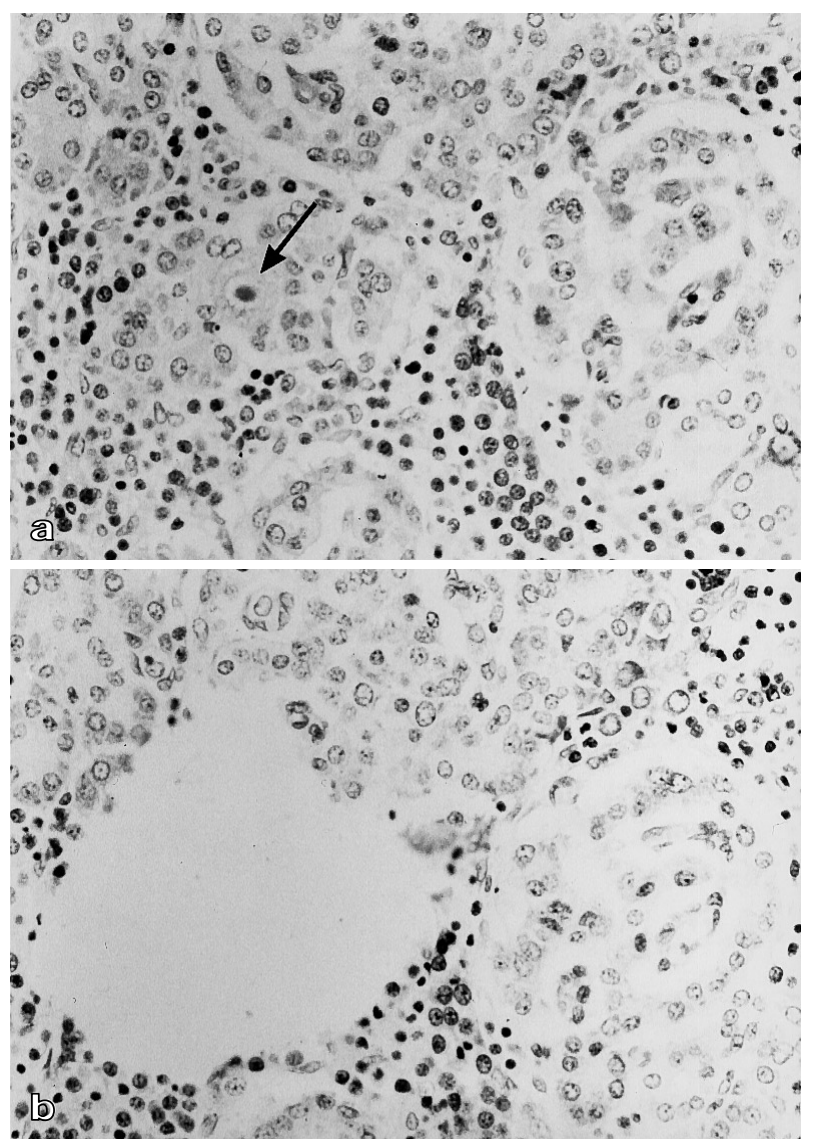

Fig. 1a,b. Cytomegalovirus infection in the pancreas of a child. A single infected cell present in the top photograph (a) (arrow) was microdissected out from an adjacent section (b) (Toluidine Blue $\times 600$ )

myocarditis. Culture of urine in life had grown coxsackievirus $\mathrm{B}_{4}$, and the autopsy had been performed two and a half days after death. Two additional controls were done on all pancreatic sections to check the preservation of $\mathrm{mR} \mathrm{NA}$ in the tissue sections. A digoxigenin labelled 20 mer poly dT probe ( 0 swel) to detect $m R$ N A poly $A$ tails was hybridized at $37^{\circ} \mathrm{C}$ overnight at 
a concentration of $1 \mathrm{ng} / \mu \mathrm{l}$. Sections in this control were pretreated with proteinase $\mathrm{K}$ at $20 \mu \mathrm{g} / \mathrm{ml}$. A 24 mer alkaline phosphatase labelled probe to insulin mR N A was synthesized (O swel) (Table 1) and applied to sections at a concentration of $1 \mathrm{ng} / \mu \mathrm{l}$ in buffer without formamide, overnight at $37^{\circ} \mathrm{C}$. Sections here were pre-treated with proteinase $\mathrm{K}$ at $20 \mu \mathrm{g} / \mathrm{ml}$. O nly those cases of diabetes where there was positive staining with both these probes were included in the study (see "selection of cases").

A II sections were also analysed using a non-relevant probe (to arginine vasopressin). This 27 mer probe ( 0 swel) (Table 1) was applied under identical conditions to the coxsackieviral probe cocktail following proteinase $\mathrm{K}(20 \mu \mathrm{g} / \mathrm{ml})$ pretreatment. A II sections were analysed by two independent observers.

Mumps virus study. We screened 19 murine monoclonal antisera to mumps viral proteins for their ability to detect mumps viral proteins by immunocytochemistry in infected rhesus kidney tissue culture cells which had been formalin fixed and paraffin embedded. Six of the antibody clones were directed towards the mumps fusion protein, 6 towards the nucleocapsid protein, 4 towards the polymerase protein and 3 towards the membrane protein. These clones have been described previously $[23,24]$. O ne of these (N P2132), which detects a nucleoprotein epitope present on all strains of mumps virus tested [24], was capable of detecting virus in this system when used a dilution of 1 in 400. This antibody was subsequently used to screen sections of diabetic pancreas and mumps infected control tissues. Sections were dewaxed and rehydrated and a 1 in 400 dilution of the antibody placed on the sections for an overnight incubation at $4^{\circ} \mathrm{C}$. A standard indirect immunoperoxidase technique was used where the second antibody was peroxidase conjugated goat anti-mouse serum (Dako, High Wycombe, UK). Diaminobenzidine was used as the subsequent substrate. For each test case a second section was analysed where normal mouse serum, diluted 1 in 400 was substituted for the monoclonal antiserum. Formalin-fixed mumps infected rhesus kidney cells were used as a positive control in all runs. Sections were analysed by 2 independent observers.

\section{EBV study}

i) PCR technique. The method used was that described in detail by Coates et al. [25]. B riefly, extraction of D NA was identical to that described in the CM V study. D etails of the primers used ( $E B V W_{1}$ and $E B V W_{2}$, synthesized by $O$ swel) are given in Table 1. These flanked a 153 base pair of the $B$ am $H 1$ ' $W$ ' internal repeat sequence of the E BV genome. E ach amplification cycle consisted of a denaturation step at $94^{\circ} \mathrm{C}$ for $1 \mathrm{~min}$, primer annealing at $60^{\circ} \mathrm{C}$ for $30 \mathrm{~s}$ and extension at $72^{\circ} \mathrm{C}$ for $1 \mathrm{~min}$. Cycles were preceded by $2 \mathrm{~min}$ at $94^{\circ} \mathrm{C}$ to ensure full denaturation of the target DNA . A two-staged procedure was performed in which extracted DNA samples were subjected to an initial 25 cycles of amplification. A small aliquot was then removed and added to fresh amplification reagents. Samples were then subjected to a further 25 cycles of amplification. The conditions for visualising the product were as used for the CM V technique.

ii) In situ hybridization technique. For this part of the study a kit provided by Dako (Code No.Y 017) was used. The technique used five 30-mer oligonucleotides labelled with the hapten fluorescein isothiocyanate (FITC). These were visualised using the Dako in situ hybridization Detection Kit (Dako Code N 0.K 0074) in which an alkaline phosphatase conjugated
Table 2. Cytomegalovirus study: results of PCR analysis

\begin{tabular}{lcl}
\hline Tissue & $\mathrm{Nn}$. of cases & $\begin{array}{l}\text { Cytomegalo- } \\
\text { virus positive }\end{array}$ \\
\hline Normal autopsy paediatric & 32 & 0 \\
pancreas & 9 & 0 \\
Normal autopsy adult pancreas & 10 & 3 \\
A utopsy A ID S pancreas & & \\
Tissues from patients with known & 5 & 3 \\
cytomegalovirus infection & 47 & 0 \\
IDD M pancreases & & \\
\hline
\end{tabular}

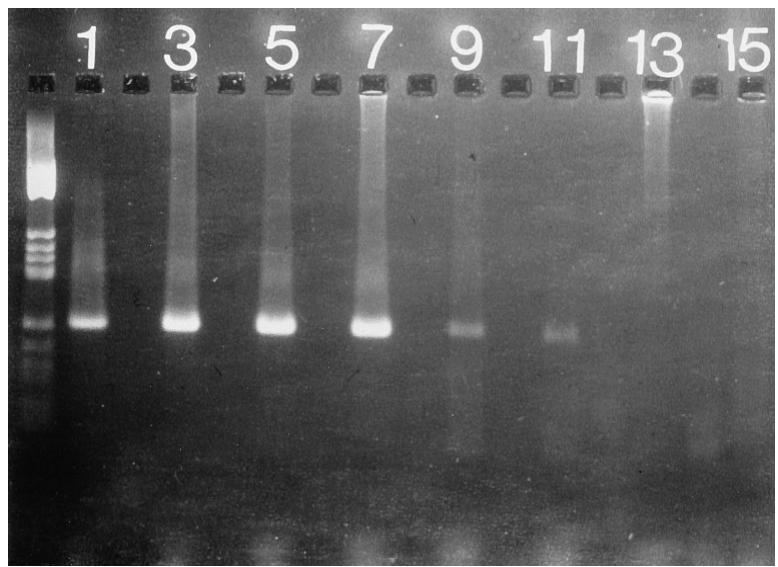

Fig. 2. A garose gel stained by ethidium bromide and viewed under ultraviolet light. DNA was extracted from a single $10 \mu \mathrm{m}$ section of the CM V control pancreas, diluted and amplified by PCR. In lane 1 the dilution of extracted D NA was $10^{-1}$ in distilled water prior to amplification, in lane $3,10^{-2}$; in lane $5,10^{-3}$; in lane $7,10^{-4}$; in lane $9,10^{-5}$; in lane $11,10^{-6}$; in lane $13,10^{-7}$. $R$ eaction product is still visible in lane 11

anti-F ITC antiserum is applied and the reaction visualised with NBT, BCIP solution. The procedures described with the kits were followed without modification. Negative controls in which the oligonucleotides were omitted were run for each case. The deoxyribo-oligonucleotides used in the kit are complementary to the 2 nuclear EBER RNAs encoded by the E BV which are highly expressed in both latent and active infection.

\section{Results}

CM V Study. A s can be seen from Table 2 no evidence of $C M V$ was found in the diabetic pancreases. This raises the question of the sensitivity of the technique. Dilution experiments were performed on DNA extracted from a single $10-\mu \mathrm{m}$ section of formalin-fixed autopsy pancreas of a neonate who died of disseminated CM V. The section adjacent to the one analysed contained 52 infected cells, as judged by standard immunocytochemisty. Extracted D N could be diluted to 1 part per 1 million parts of distilled water and still give a positive signal after PCR (Fig.2). D NA was extracted from the micro dissected "owl's eye" cell 
(Fig. 1) and the CM V sequence was still amplifiable after 500 -fold dilution. A II 3 A ID S pancreases which had immunocytochemically identifiable infected CMV cells were correctly found to be positive as were the tissues from 3 of the 5 cases of clinical CM V infection. I $n$ the case of the 2 negative samples, the patients had been treated for the infection and the tissue analysed (lung) had no demonstrable CM V infected cells on immunocytochemical analysis.

Coxsackievirus study. None of the pancreases from patients with IDDM had demonstrable coxsackievirus R NA. A II pancreases studied had well-preserved mRNA (insulin mRNA and polyA). Evidence of coxsackieviral infection was readily discernible in 13 out of 14 hearts of the infants who died of myocarditis (Table 3, Fig. 3). In these cases the pancreas was infected by virus in 5 out of 9 cases and islets were particularly affected (Fig. 4). O nly occasional acinar cells stained positively. B rown fat, usually sampled next to the adrenal, was also frequently positive. In the infants who had died of myocarditis all tissues not mentioned in Table 3 were negative, including samples of lung and brain. A II pancreatic sections were stained using the probe to arginine vasopressin and no positive cells were identified. When sections of the positive control heart were treated with RNA -ase prior to hybridization no staining was observed following the standard procedure.

M umps virus study. Pancreases from all 75 cases of ID D M were negative. In the salivary glands sampled from the children with mumps infection there was striking intralobular duct necrosis with accumulation of debris in duct lumens. A $n$ intense chronic inflammatory cell infiltrate was present which was clearly centred on the intralobular ducts. I mmunocytochemistry demonstrated mumps virus in the ductal epithelial cells and the intraduct debris in 2 of the 3 cases (Fig.5) both of whom had had infection for a short time (1-3 days). In the third patient there was clear histological evidence of duct epithelial regeneration and no positive duct cells were present. D eath in this case occurred 7 days after the onset of clinical mumps infection. Salivary gland acinar cells were negative in all cases.

Pancreas was available in the 3 cases of mumps infection and a single small area of exocrine pancreatic necrosis was present in the patient with mumps of 7 days duration. No virus was demonstrable in any pancreatic tissue sampled.

E BV study. D iabetic pancreases studied by both the $P C R$ and in situ hybridization techniques were uniformly negative. Both positive control cases were positive by both techniques, although there was considerable autolysis in the tissue section of the autopsy post-transplant lymphoproliferative disorder (Fig. 6).
Table 3. R esults of coxsackievirus study

\begin{tabular}{llrl}
\hline Disease & Tissue & No. tested & No. positive \\
\hline Infantile myocarditis & & \\
& H eart & 14 & 13 \\
& Pancreas & 9 & 5 \\
& B rown fat & 9 & 5 \\
& A drenal cortex & 10 & 2 \\
& Liver & 9 & 1 \\
& Skeletal muscle & 6 & 1 \\
& A nterior pituitary & 1 & 1 \\
IDDM & & & \\
& Pancreas & 29 & 0 \\
\hline
\end{tabular}

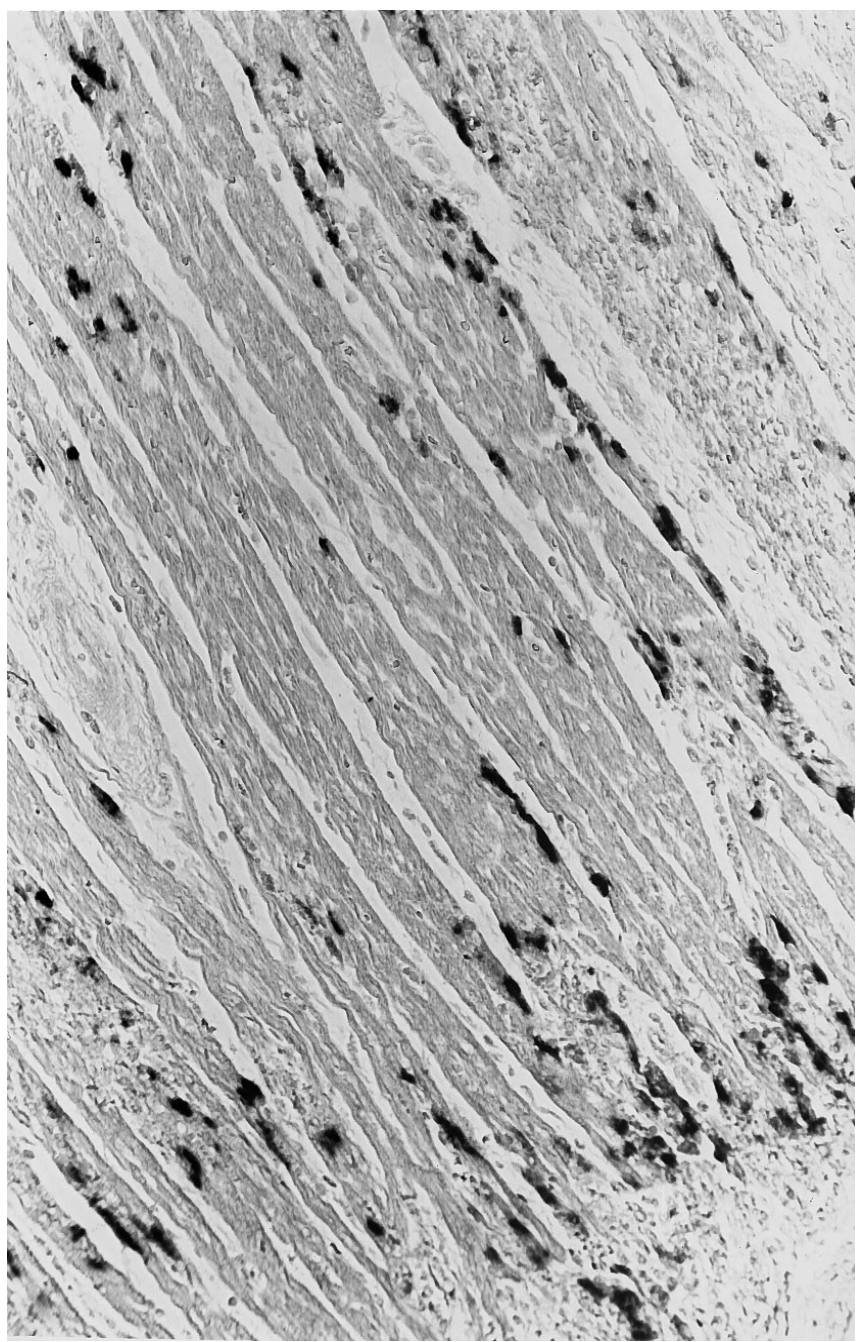

Fig. 3. Coxsackie virus B 4 infection in the heart of a 13-day-old infant. Numerous cardiac myocytes contain enteroviral R NA (in situ hybridization for coxsackie virus $\times 150$ )

\section{Discussion}

D eaths from IDDM at clinical presentation are very rare and attempts at viral culture at autopsy are seldom reported. The aim of the present study was to use techniques on stored autopsy pancreases which 


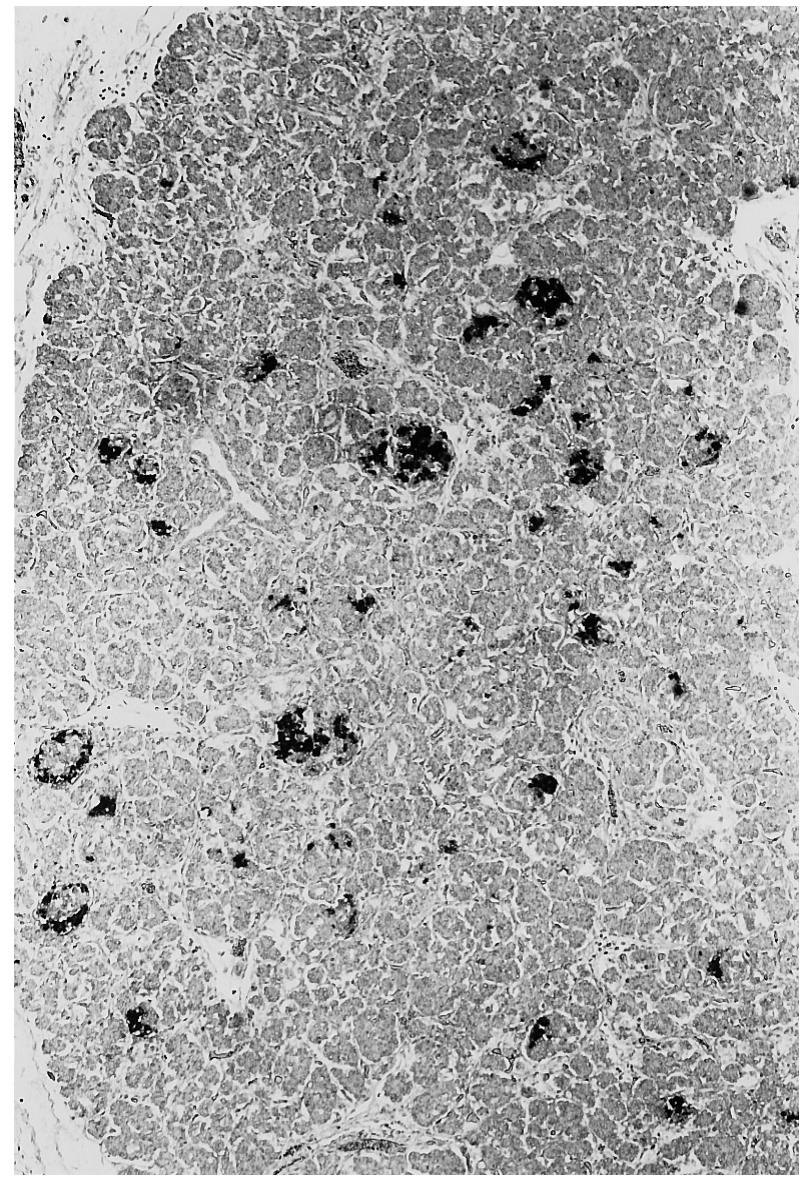

Fig. 4. Coxsackie virus B 3 infection in the pancreas of a 9-dayold infant. There is tropism of the virus to islets of $L$ angerhans (in situ hybridization for coxsackievirus $\times 60$ )

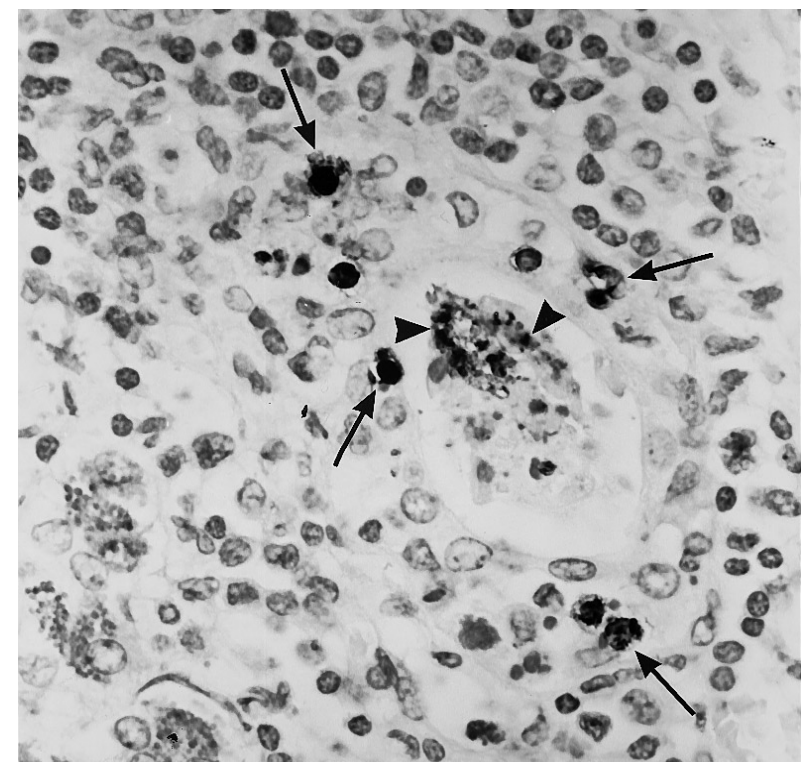

Fig. 5. M umps infection of salivary gland in a 16-year-old girl. $\mathrm{H}$ ere there is a small salivary duct surrounded by inflammatory cells. N ecrotic debris is present in the duct lumen. $V$ irus is present in numerous ductal epithelial cells (arrows) as well as the luminal debris (arrowhead). (Indirect immunoperoxidase with monoclonal antibody N P2132 × 600)

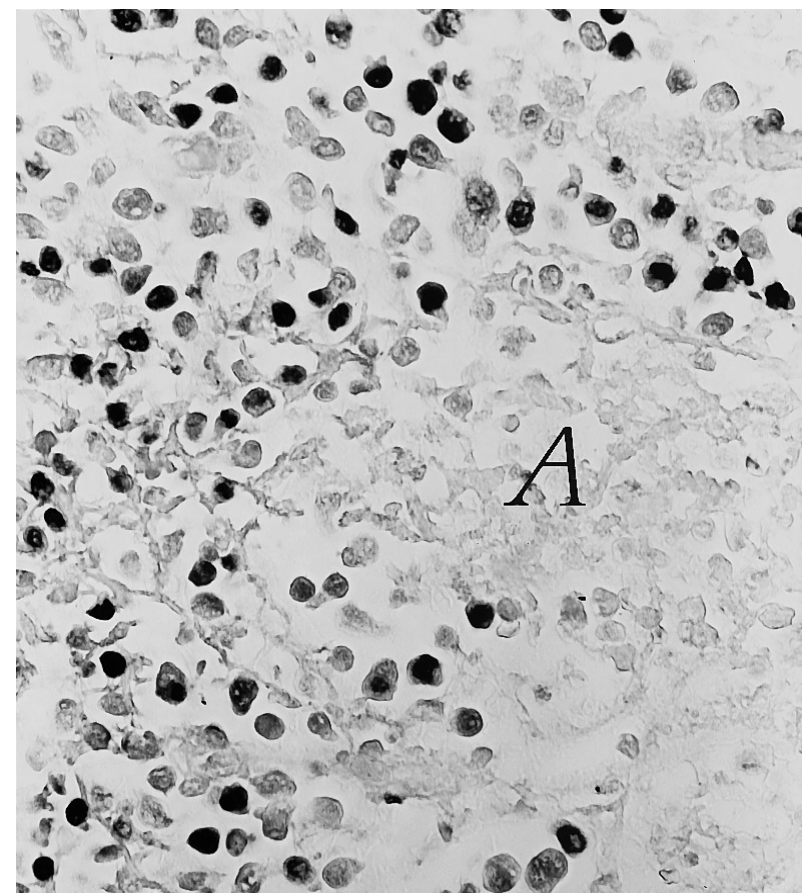

Fig. 6. Post-transplant Iymphoproliferative lesion in autopsy lung. EBV can be demonstrated in these cells in spite of the presence of widespread autolysis (A). (in situ hybridization for E BV $\times 375$ )

are as sensitive as viral culture in detecting virus, to determine whether diabetogenic viruses could have been cultured from the pancreases at their respective autopsies had culture been attempted.

In the event that no evidence for either $\mathrm{CM} \mathrm{V}$, coxsackievirus, EBV or mumps virus could be found in the diabetic pancreases studied, the question is raised as to how appropriate the techniques used really were. The PCR method employed to identify CM V appeared to be exquisitely sensitive, being able to detect evidence of 52 infected cells in a section of pancreas following a $10^{6}$ dilution of extracted D N A . Coxsackieviral R NA was demonstrable in the heart by in situ hybridization in 13 out of 14 infants with myocarditis and positive staining was easily seen even in autopsies done several days after death (Fig. 3). The patient in whom no infected cells were seen was aged 10 months. Diagnosis had been made in life from a stool culture and no viral culture was done at autopsy. Coxsackie $B$ virus was cultured from the heart at autopsy in 7 of the infants in the myocarditis study and virus was demonstrable in the heart by in situ hybridization in each case. No attempt was made to culture mumps virus at the autopsies of the 3 positive control children who had died of that infection, the diagnosis having been made clinically. H owever, immunocytochemistry clearly demonstrated positive staining for virus in those salivary ductal cells which exhibited a cytopathic effect. B oth techniques used in the EBV part of the study were capable of 
detecting virus in partially autolysed autopsy tumour tissue.

A reasonable conclusion from the present study, therefore, is that had pancreatic viral culture been done at the time of autopsy on the 47 diabetic patients in the CM V study, the 29 patients in the coxsackie study, the 75 patients in the mumps study and the 47 patients in the EBV study, these respective viruses would not have been cultured.

0 ther studies, of smaller numbers of patients, also failed to detect evidence of viral infection in diabetic pancreases [26-28]. What therefore is the explanation for the positive culture of a coxsackievirus B 4 in the autopsy studied by $Y$ oon et al. [1]? That child had a family history of IDD M. He presented with ketoacidosis but also developed clinical signs of meningitis. D uring life there was a rising serological titre to the virus cultured at autopsy, which makes it unlikely that the virus was a laboratory contaminant. However, only one of two attempts to culture virus from the pancreas was successful and virus could not be demonstrated by immunofluorescence in the pancreas. Immunofluorescence did identify the virus in the brain stem of the patient. The histology of the pancreas appears to have been typical of IDD M ([1] and $\mathrm{G}$ epts W personal communication) with insulindeficient islets and insulitis but little evidence of the dramatic beta-cell necrosis which characterises coxsackieviral pancreatitis in infants [29]. IDDM appears usually to be a disease of slow evolution with evidence of endocrine dysfunction, and presumably beta-cell loss, months or even years before clinical presentation [12]. It is therefore possible that this child had already lost a critical number of beta cells through the typical autoimmune process and that the clinical presentation of diabetes was provoked by a severe coxsackieviral infection, accompanied by viraemia, affecting primarily the brain, i. e. the virus may not have been primarily responsible for the beta-cell loss in this child.

If an acute viral infection is unlikely as a cause of IDD M, would the techniques used here be able to detect a low-grade persistent infection? The PCR technique for detection of $C M V$ was the same as that used by $\mathrm{H}$ attersley et al. [15]. A Ithough they were unable to detect CM V in the autopsy pancreases of their patients with NIDDM, they could detect the virus in samples found to be positive in the study by Lohr and O Idstone [30]. In this latter study samples were positive in the absence of inflammation or classical histological features of CMV infection. Foulis et al. [29] found no immunohistochemical evidence of the V P-1 coxsackieviral protein in IDDM pancreases. It was argued then that this capsid protein may only be expressed significantly in a lytic infection of cells as opposed to a persistent infection. This was the rationale for using an in situ hybridization technique in the present study, since nucleic acid would still be expected to be present in a non-cytopathic infection. The question of enteroviral persistence in human pathology is unresolved with several studies suggesting that it does occur in idiopathic dilated cardiomyopathy [31, 32] and chronic inflammatory muscle disease [33] but there have been doubters [34, 35]. These studies have been done on fresh tissue biopsies of heart and skeletal muscle and this clearly is a more ideal starting point than autopsy pancreas, as examined here. A s there is little evidence that PCR for enterovirus offers a more sensitive method of detecting enterovirus in autopsy tissues [21], the question of whether the inability to detect enterovirus in the present study is a false negative must currently remain an open one.

A $n$ alternative strategy to detect persisting enteroviral infection in diabetic patients has recently been employed [36]. Serum of newly diagnosed diabetic children was examined for the presence of enteroviral RNA, using PCR. Nine of 14 diabetic patients had positive samples compared to 2 of 45 nondiabetic children. Sequencing of the amplified nucleic acid showed a high degree of similarity with published sequences of coxsackieviruses B 3 and B 4 . These potentially important findings await confirmation.

It has frequently been argued that if there was immunological cross reactivity between a virus and a beta-cell antigen then an immune response to eliminate the virus could cause continuing damage to beta cells. Such cross reactivity has been suggested for enterovirus and glutamic acid decarboxylase, the islet autoantigen [37, 38], and CM V and a $38 \mathrm{kDa}$ protein present in islet endocrine cells [39]. There is indeed a murine model of diabetes where coxsackieviral infection of the pancreas is followed by the appearance of anti $64 \mathrm{kDa}$ antibodies and diabetes. The virus is not culturable after the first week [40, 41]. While antigen cross reactivity is a very plausible scenario, the immunopathology of the diabetic human pancreas does not appear to accord with it. A clear finding in both the prediabetic $[42,43]$ and diabetic [44] pancreas is that beta cells in many islets which are not inflamed express interferon-alpha [13]. This finding suggests a continuing abnormality of the beta cell (production of interferon-alpha) in the absence of any obvious immune attack. A $n$ immune response caused by a cross reaction between a non-persisting pathogen and an islet autoantigen would more likely cause insulitis without interferonalpha expression by the beta cells.

The most obvious explanation for the finding that beta cells express interferon-alpha in IDDM is that they harbour a persistent viral infection. We have failed to detect any evidence of such infection in this study but the recent report that islet cells from IDDM pancreases may contain a superantigen [9] suggests that infections may be involved other than 
those caused by the common viruses studied here. Retroviruses can act as superantigens and preliminary data suggest that a relevant retrovirus could be present in human ID D M pancreas [45].

A cknowledgements. The authors are grateful to Dr. C.Örvell for his generous gift of monoclonal antibodies to mumps virus proteins. Dr. J.J.Going performed the micro dissections on the CMV case and M s. J.Cramb kindly prepared the manuscript. The study was supported by grant nn. \# 191125 from the J uvenile D iabetes Foundation International.

\section{References}

1. Y oon J -W, A ustin M, O nodera T, Notkins A L (1979) Virus induced diabetes mellitus. N Engl J M ed 300: 1173-1179

2. G ladisch R, H ofmann W, Waldherr R (1976) M yokarditis und insulitis nach Coxsackie-Virus-Infekt. Z eitschrift für Kardiologie 65: 837-849

3. B anatvala J E , Bryant J, Schernthaner G et al. (1985) C oxsackie $B$, mumps, rubella, and cytomegalovirus specific IgM responses in patients with juvenile-onset insulin-dependent diabetes mellitus in B ritain, A ustria and A ustralia. L ancet i: 1409-1412

4. Federlin K, O tten A, H elmke K (1987) I slet cell antibodies and viral infections. Exp Clin E ndocrinol 89: 368-374

5. L udvigsson J , Forsberg P, Fryden A, L indblom B, M arshall M O, von Schenck H (1988) Mumps with laboratory signs of subclinical pancreatitis may cause a disturbed beta-cell function. D iabetes R esearch 9: 193-195

6. Forrest J M, Menser MA, Burgess JA (1971) High frequency of diabetes mellitus in young adults with congenital rubella. $L$ ancet 2: 332-334

7. G insberg-Fellner F, Witt ME, Fedun B et al. (1985) Diabetes mellitus and autoimmunity in patients with the congenital rubella syndrome. R eviews of Infectious Diseases 7: [Suppl 1] S170-S176

8. Pak CY, E un H-M , M cA rthur R G, Y oon J -W (1988) A ssociation of cytomegalovirus infection with autoimmune type 1 diabetes. L ancet ii: 1-4

9. Conrad B, Weidmann E, Trucco G et al. (1994) E vidence for superantigen involvement in insulin-dependent diabetes mellitus aetiology. N ature 371: 351-355

10. Smith TJ, Terada N, Robinson CC, Gelfand EW (1993) A cute infectious mononucleosis stimulates the selective expression/expansion of $\mathrm{V}$ beta $6.1-3$ and $\mathrm{V}$ beta $7 \mathrm{~T}$ cells. Blood 81: 1521-1526

11. $H$ yöty $H$, R äsänen $L$, Hiltunen $M$, L ehtinen $M, H$ uupponen T, Leinikki $P$ (1991) Decreased antibody reactivity to $E$ pstein-Barr virus capsid antigen in type 1 (insulin-dependent) diabetes mellitus. A PM IS 99: 359-363

12. Tarn A C, Smith CP, Spencer K M , B ottazzo G F, G ale E A M (1987) Type 1 (insulin dependent) diabetes: a disease of slow clinical onset? B M ed J 294: 342-345

13. Foulis A K , Farquharson M A , Meager A (1987) I mmunoreactive alpha-interferon in insulin-secreting beta cells in type 1 diabetes mellitus. L ancet ii: 1423-1427

14. Foulis AK, Liddle CN, Farquharson MA, R ichmond JA, Weir RS (1986) The histopathology of the pancreas in type 1 (insulin-dependent) diabetes mellitus: a 25-year review of deaths in patients under 20 years of age in the United Kingdom. Diabetologia 29: 267-274

15. H attersley A T, L o Y-M D, R ead SJ, E glin R P, Wainscot J S, Clark A (1992) Failure to detect cytomegalovirus D NA in pancreas in type 2 diabetes. $L$ ancet 339: 335-336
16. W right DK, M anos M M (1990) Sample preparation from paraffin-embedded tissues. In: Innis MA, Gelfand DH, Sninsky JJ, White JJ (eds) PCR protocols: A guide to methods and applications. A cademic press Inc, San D iego, New York, Boston, London, Sydney, Tokyo, Toronto pp 154- 156

17. Sternberg RM, Thomson DR, Stenski MF (1984) Structural analysis of the major intermediate early gene of human cytomegalovirus. J Virol 49: 190-199

18. A krigg A, Wilkinson G W G, O ram J D (1985) The structure of the major immediate early gene of human cytomegalovirus strain A D 169. Virus R esearch 2: 107-121

19. Saiki RK, Scharf S, Faloona F et al. (1985) E nzymatic amplification of $\beta$-globin genomic sequences and restriction site analysis for diagnosis of sickle cell anaemia. Science 230: 1350-1354

20. Hilton DA, D ay C, Pringle JH, Fletcher A, Chambers $S$ (1992) D emonstration of the distribution of coxsackie virus RNA in neonatal mice by non-isotopic in situ hybridization. J Virol Methods 40: 155-162

21. H ilton DA, Variend S, Pringle JH (1993) Demonstration of coxsackie virus R N A in formalin-fixed tissue sections from childhood myocarditis cases by in situ hybridization and the polymerase chain reaction. J Pathol 170: 45-51

22. Farquharson M, H arvie R, M cNicol A M (1990) Detection of messenger R N A using a digoxigenin end labelled oligodeoxynucleotide probe. J Clin Pathol 43: 424-428

23. Orvell C (1984) The reactions of monoclonal antibodies with structural proteins of mumps virus. J Immunol 132: 2622-2629

24. R ydbeck R, Löve A, Örvell C, Norrby E (1986) A ntigenic variation of envelope and internal proteins of mumps virus strains detected with monoclonal antibodies. J Gen Virol 67: 281-287

25. Coates PJ, d'A rdenne AJ, K han G, Kangro H O, Slavin G (1991) Simplified procedures for applying the polymerase chain reaction to routinely fixed paraffin wax sections. J Clin Pathol 44: 115-118

26. B uesa-G omez J, de la Torre J C, D yrberg T et al. (1994) Failure to detect genomic viral sequences in pancreatic tissues from two children with acute-onset diabetes mellitus. J Med Virol 42: 193-197

27. Foy CA, Q uirke P, Williams DJ et al. (1994) A search for candidate viruses in type 1 diabetic pancreas using the polymerase chain reaction. D iabet M ed 11: 564-569

28. I toh N, H anafusa T, Y amagata K et al. (1995) No detectable cytomegalovirus and $E$ pstein-Barr virus genomes in the pancreas of recent onset IDDM patients. Diabetologia 38: 667-671

29. Foulis $A K$, Farquharson MA, Cameron SO, M CGill M, Schönke H, Kandolf R (1990) A search for the presence of the enteroviral capsid protein VP1 in pancreases of patients with type 1 (insulin dependent) diabetes and pancreases and hearts of infants who died of coxsackieviral myocarditis. D iabetologia 33: 290-298

30. L ohr J M, O Idstone M BA (1990) D etection of cytomegalovirus nucleic acid sequences in pancreas in type 2 diabetes. $L$ ancet 336: 644-648

31. B owles NE , R ichardson PJ, O Isen E G J , A rchard L C (1986) $D$ etection of coxsackie-B -virus-specific R NA sequences in myocardial biopsy samples from patients with myocarditis and dilated cardiomyopathy. L ancet $\mathrm{i}$ : 1120-1122

32. E ditorial (1990) D ilated cardiomyopathy and enteroviruses. L ancet 336: 971-972

33. B owles NE, Dubowitz V, Sewry CA, A rchard LC (1987) Dermatomyositis, polymyositis and coxsackie-B-virus infection. L ancet i: 1004-1007 
34. L eff $R L$, L ove LA, M iller FW et al. (1992) Viruses in idiopathic inflammatory myopathies: absence of candidate viral genomes in muscle. L ancet 339: 1192-1195

35. Hilton DA, F letcher A, Pringle JH (1994) A bsence of coxsackie viruses in idiopathic inflammatory muscle disease by in situ hybridization. Neuropath A pplied Neurobiol 20: 234-242

36. Clements GB, Galbraith DN, Taylor KW (1995) Coxsackie $B$ virus infection and onset of childhood diabetes. L ancet 346: 221-223

37. Tian J, L ehmann PV, K aufman D L (1994) T cell cross reactivity between coxsackievirus and glutamate decarboxylase is associated with a murine diabetes susceptibility allele. J Exp M ed 180: 1979-1984

38. A tkinson $M A, B$ owman $M A, C$ ampell $L, D$ arrow $B L$, Kaufman DL, M acL aren NK (1994) Cellular immunity to a determinant common to glutamate decarboxylase and coxsackie virus in insulin-dependent diabetes. J Clin Invest 94: 2125-2129

39. Pak CY, Cha CY, Rajotte RV, M CA rthur RG, Y oon JW (1990) Human pancreatic islet cell specific 38 kilodalton autoantigen identified by cytomegalovirus-induced monoclonal islet cell autoantibody. D iabetologia 33: 569-572
40. Gerling I, Nejman C, Chatterjee N (1988) E ffect of coxsackievirus B 4 infection in mice on expression of $64 \mathrm{~K}$ autoantigen and glucose sensitivity of islets before development of hyperglycaemia. D iabetes 37: 1419-1425

41. G erling I, Chatterjee N K, N ejman C (1991) Coxsackievirus B 4-induced development of antibodies to 64,000-M islet autoantigen and hyperglycaemia in mice. Autoimmunity 10: $49-56$

42. Foulis A K, Jackson R, Farquharson M A (1988) The pancreas in idiopathic A ddison's disease - a search for a prediabetic pancreas. H istopathology 12: 481-490

43. Foulis A K, M cG ill M, Farquharson M A (1991) Insulitis in type 1 (insulin-dependent) diabetes mellitus in man-macrophages, lymphocytes and interferon-gamma containing cells. J Pathology 165: 97-103

44. Foulis A K , Farquharson M A , H ardman R (1987) A berrant expression of class II major histocompatibility complex molecules by $B$ cells and hyperexpression of class I major histocompatibility complex molecules by insulin containing islets in type 1 (insulin-dependent) diabetes mellitus. Diabetologia 30: 333-343

45. Y oon J-W (1995) A new look at viruses in type 1 diabetes. Diabetes M etab R ev 11: 83-107 